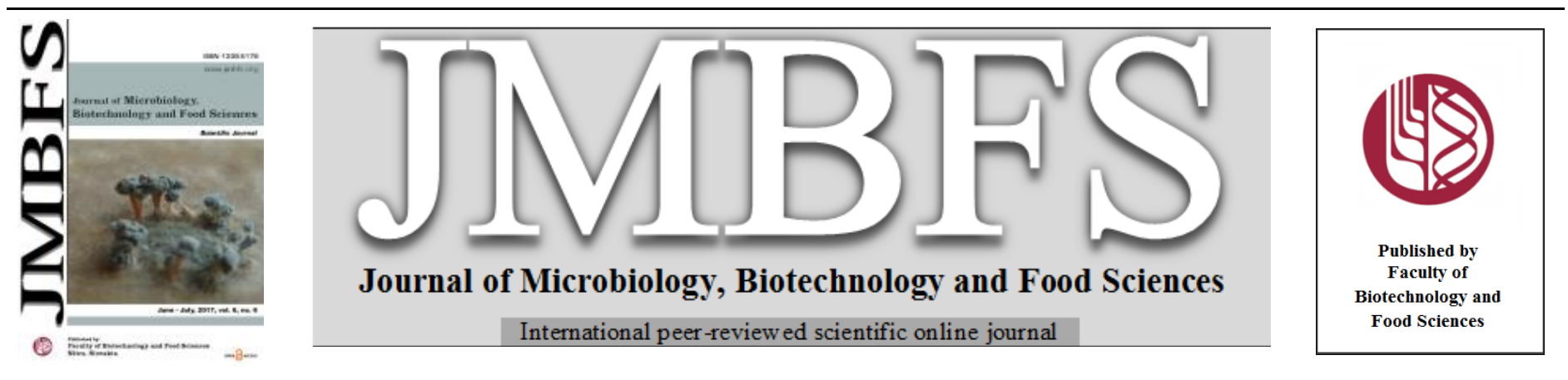

\title{
MANUFACTURE OF BIO-LABNEH USING ABT CULTURE AND BUFFALO AND SOY MILK MIXTURES
}

\section{Magdy M. Ismail ${ }^{1 *}$, Gehan A. Ghoneem ${ }^{2}$, Naeem A. EL-Boraey ${ }^{2}$, Mohamed M. Tabekha ${ }^{2}$ and Hoda F. Elashrey ${ }^{1}$}

\author{
Address(es): \\ ${ }^{1}$ Dairy Technology Department, Animal Production Research Institute, Agricultural Research Center, Dokki, Giza, Egypt. \\ ${ }^{2}$ Food Industries Department, Faculty of Agriculture, Mansoura University, El-Mansoura, Egypt.
}

*Corresponding author: magdy250@yahoo.com

doi: $\underline{10.15414 / j \mathrm{mbfs} .2017 .6 .6 .1237-1245}$

\section{ARTICLE INFO}

Received 23. 12. 2016

Revised 27. 3. 2017

Accepted 20. 4. 2017

Published 1. 6. 2017

Regular article

OPEN $\partial_{\text {ACCESS }}$

\begin{abstract}
The effect of using soy milk and ABT culture on various Labneh properties was investigated. Six treatments of Labneh were made from soy and buffalo milk and from their mixtures using classic and ABT-5 starters. Labneh made from soy milk had the lowest yield, acidity, redox potential $\left(\mathrm{E}_{\mathrm{h}}\right.$ ), total solids (TS), fat, ash, TN, TVFA, saturated fatty acids (SFA), monounsaturated fatty acids (MUSFA), and total amino acids contents while buffalo's milk Labneh had the highest. Soy milk Labneh had the highest level of unsaturated fatty acids (USFA), polyunsaturated fatty acids (PUSFA) and linoleic acid and $\alpha$-linolenic acid. Also, soy milk Labneh had the greatest count of Str. thermophillus, L. acidophilus and bifidobacteria. Utilization of soy milk only or mixed with buffalo milk in Labneh manufacture decreased the count of $L$. bulgaricus. Mixing of buffalo milk with soy milk increased the sensory evaluation scores of Labneh. Classic starter Labneh had higher values of yield, acidity, WSN, TVFA, SFA and lower values of $\mathrm{pH}$ than those of ABT Labneh. Using of ABT culture in Labneh manufacturing increased USFA and total free amino acids contents. ABT Labneh had higher numbers of Str. thermophillus than those of classic starter.
\end{abstract}

Keywords: Soy milk, ABT, Buffalo milk, Labneh

\section{INTRODUCTION}

In the Middle East region, concentrated yoghurt (Labneh) is highly appreciated and consumed with bread all year a round. Labneh is an important supplement to the local diet and provides vital elements for growth and good health (Shamsia and El-Ghannam, 2012). According to Lebanese standards, Labneh is defined as a semisolid food derived from yogurt by draining away part of its water and water-soluble compounds (Mohameed et al., 2004). Usually, Labneh is prepared with two solids concentration. The first is $22 \%$ where Labneh is prepared to be consumed within two weeks and usually stored in refrigerators. The second is $40 \%$ and Labneh is stored in vegetable oil at room temperature and can be consumed within two years (Keceli et al., 1999).

On the other hand, soybean-based products are very popular and have attracted worldwide interest. China, the largest importing country to domesticate soybeans and a major global soybean grower and consumer, has extensive distributions of soybean accessions (Li et al., 2014). Soya milk is the biggest soya-based product consumed in the world, not only because of its potential health benefits but also as an alternative to cow milk targeting for lactose-intolerant individuals, those allergic to milk proteins, or those avoiding consuming milk for other reasons (Reilly et al., 2006). It is made from soaked soybeans by grinding, heating, and filtering (Ikya et al., 2013).

ABT culture (Lactobacillus acidophilus, Bifidobacterium spp., and Streptococcus thermophilus) was chosen for soymilk fermentation because of the positive interaction between probiotic strains Bifidobacterium spp., and Lactobacillus acidophilus (Tamime et al., 2005). Besides that, Streptococcus thermophilus is always the dominant strain in mixed cultures and shows the greatest growth regardless of the fermentable substrates, e.g. in cow milk, goat milk (Božanić et al., 2002), or in soymilk (Božanić et al., 2008). The healthy importance of probiotic bacteria was established from many decades ago. To overcome the loss of viability of probiotic bacteria, the present trend is to use starter cultures for yoghurt production with no Lactobacillus delbrueckii subsp. bulgaricus, such as ABT. S. thermophiles, which is less proteolytic than L. bulgaricus, is the main organism responsible for fermentation in ABT cultures (Parmar, 2003). The objective of this study was to test the possibility of manufacturing of Labneh from soy and buffalo milk using classic and ABT cultures. Chemical composition, bacteriological parameters and sensory evaluation of Labneh were monitored.

\section{MATERIALS AND METHODS}

\section{Milk, Soybeans and Starter Culture}

Fresh buffalo's milk was obtained from private farm in Damiette Governorate, Egypt. Yellow soybeans (Glycine max (L.) were purchased from a local grocery in Damiette Governorate.

A commercial classic yoghurt starter containing Streptococcus thermophillus and Lactobacillus delbrueckii subsp. bulgaricus (1:1) and ABT-5 culture which consists of $S$. thermophiles, Lactobacillus acidophilus + B. bifidum (Chr Hansen's Lab A/S Copenhagen, Denmark) were used. Starter cultures were in freeze-dried direct-to-vat set form and stored at $-18^{\circ} \mathrm{C}$ until used.

\section{Preparation of Soymilk}

Beans of good quality were carefully selected and soaked overnight $12-18 \mathrm{~h}$, at room temperature in ultrapure water contained $0.5 \% \mathrm{NaHCO}_{3}$. Once soaked, water was discarded and the grains were re-soaked in boiling water for $15 \mathrm{~min}$ then, hulls were removed under running water by manual rubbing. The peeled soybeans were next rinsed and drained with cold water several times. Of the water to be added to the soaked beans (1:6 beans: water ratios), about half was added at room temperature $\left(23^{\circ} \mathrm{C}\right)$ and blended with the beans at high speed for $10 \mathrm{~min}$. The remaining water was heated to $80^{\circ} \mathrm{C}$ and added to the slurry to enhance protein extraction. This mixture was blended for an additional 3 min. at high speed. The resultant slurry was filtered through 3 layers of cheese-cloth to remove coarse material (okara, which is mainly composed of insoluble fiber material). Thereafter, the isolated soymilk was boiled on a low heat for $5 \mathrm{~min}$. to destroy trypsin inhibitor for improving flavor and cooled down to $25^{\circ} \mathrm{C}$ (Ikya $e t$ al., 2013).

\section{Labneh Preparation}

Labneh was made using the procedure normally used in homes. Fresh milk was heated to $85^{\circ} \mathrm{C}$ for $15 \mathrm{~min}$., cooled to $40^{\circ} \mathrm{C}$, inoculated with cultures $(0.1 \mathrm{~g} / \mathrm{L}$ of yoghurt mix) and incubated at $40^{\circ} \mathrm{C}$ for fully coagulation. The produced yoghurt was left at $4^{\circ} \mathrm{C}$ overnight, mixed and put into cloth bags which were hung for 24 $\mathrm{h}$ in a refrigerator to allow for whey drainage. The resulting Labneh was mixed 
with $1.5 \%$ salt and transferred to $250 \mathrm{~g}$ plastic cups, covered with polyethylene film and stored at $5^{\circ} \mathrm{C}$ for 28 days. Chemical, bacteriological and sensorial tests were occurred in Labneh samples in fresh and after 7, 14, and 21 days of refrigerated storage. Table 1 shows various Labneh treatments.

Table 1 Labneh treatments

Abbreviations Treatments

\begin{tabular}{|c|c|}
\hline $\mathbf{A}$ & Labneh made from soy milk and classic starter \\
\hline B & Labneh made from buffalo's milk and classic starter \\
\hline $\mathbf{C}$ & $\begin{array}{l}\text { Labneh made from } 75 \% \text { buffalo's milk }+25 \% \text { soymilk } \\
\text { and classic starter }\end{array}$ \\
\hline D & Labneh made from soy milk and ABT culture \\
\hline $\mathbf{E}$ & Labneh made from buffalo's milk and ABT culture \\
\hline $\mathbf{F}$ & $\begin{array}{l}\text { Labneh made from } 75 \% \text { buffalo's milk }+25 \% \text { soymilk } \\
\text { and ABT culture }\end{array}$ \\
\hline
\end{tabular}

\section{Chemical analysis}

Total solids, fat, total nitrogen and ash contents of samples were determined according to AOAC (2000). Titratable acidity in terms of \% lactic acid was measured by titrating $10 \mathrm{~g}$ of sample mixed with $10 \mathrm{ml}$ of boiling distilled water against $0.1 \mathrm{~N} \mathrm{NaOH}$ using a $0.5 \%$ phenolphthalein indicator to an end point of faint pink color. $\mathrm{pH}$ of the sample was measured at 17 to $20^{\circ} \mathrm{C}$ using a $\mathrm{pH}$ meter (Corning $\mathrm{pH} /$ ion analyzer 350, Corning, NY) after calibration with standard buffers ( $\mathrm{pH} 4.0$ and 7.0). Redox potential was measured with a platinum electrode [model P14805-SC-DPAS-K8S/325; Ingold (now Mettler Toledo), Urdorf, Switzerland] connected to a $\mathrm{pH}$ meter (model $\mathrm{H}$ 18418; Hanna Instruments, Padova, Italy). Water soluble nitrogen (WSN) of Labneh was estimated according to Ling (1963). Total volatile fatty acids (TVFA) were determined according to Kosikowiski (1978).

\section{Determination of fatty acids composition}

The extraction of milk fat was done using the method of Rose-Gottlieb using diethyl ether and petroleum ether (Methodenbuch, Bd. VI VDLUFA-Verlag, Darmstadt, 1985). After that the solvents were evaporated on a vacuum rotary evaporator. For obtaining methyl esters of the fatty acids, sodium methylate $\left(\mathrm{CH}_{3} \mathrm{ONa}\right)$ was used (Jahreis et al., 1997).

GC condition: Rtx-5 column (oven temperature $180^{\circ} \mathrm{C}$, hold for $2 \mathrm{~min}$; increase to $270^{\circ} \mathrm{C}$ at $10^{\circ} \mathrm{C} / \mathrm{min}$, hold for $4 \mathrm{~min}$ and total of running time $15 \mathrm{~min}$. Carrier gas He $2.43 \mathrm{~mL} / \mathrm{min}$, flow rate of air $190 \mathrm{~mL} / \mathrm{min}$ and flow rate $\mathrm{H}_{2} 80 \mathrm{~mL} / \mathrm{min}$ Injector temperature is $290^{\circ} \mathrm{C}$ and temperature of flame ionization detector (FID) is $290^{\circ} \mathrm{C}$. Methyl laurat $(10 \%$ in heptana) as a standard with injection volume $0.10 \mu \mathrm{L}$. The peak of sample chromatogram having the same retention time with the retention time of standard is the peak of fatty acid.

\section{Determination of amino acids composition}

Amino acid profile of fresh yogurt was performed following the protocol of Walsh and Brown (2000). Hydrochloric acid (6 M) was added to the sample vial for a final concentration of $5 \mathrm{mg}$ of protein $/ \mathrm{mL}$ of $\mathrm{HCl}$. Hydrolysis vial was placed in an ultrasonic cleaner and flushed with nitrogen gas before sealing under vacuum. Sample was placed in a heating block for $4 \mathrm{hr}$ at $145^{\circ} \mathrm{C}$. Afterwards, sample was removed from the heating block and allowed to cool before filtration through $0.2 \mu \mathrm{m}$ filter. Sample was dried with nitrogen gas and dissolved in a dilution buffer. The prepared sample was analyzed for amino acid profile by running through Automated Amino Acid Analyzer (Model: L-8500 A, Hitachi, Japan). Areas of amino acid standards were used to quantify each amino acid in representative sample.

\section{Microbial analysis}

Labneh samples were analyzed for Lactobacillus delbrueckii ssp. bulgaricus, Streptococcus thermophiles and Lactobacillus acidophilus counts according to the methods described by Tharmaraj and Shah (2003). The count of bifidobacteria was determined according to Dinakar and Mistry (1994). A mixture of antibiotics, including $2 \mathrm{~g}$ of neomycin sulfate, $4 \mathrm{~g}$ of paromomycin sulfate, $0.3 \mathrm{~g}$ of nalidixic acid, and $60 \mathrm{~g}$ of lithium chloride (NPNL, Sigma Chemical Co.), was prepared in $1 \mathrm{~L}$ of distilled water, filter-sterilized, and stored at $4{ }^{\circ} \mathrm{C}$ until use. The mixture of antibiotics $(5 \mathrm{ml})$ was added to $100 \mathrm{ml}$ of MRS agar medium. Cysteine- $\mathrm{HCl}$ was added at the rate of $0.05 \%$ to decrease the redox potential of the medium. Plates were incubated at $37^{\circ} \mathrm{C}$ for 48 to $72 \mathrm{~h}$ under anaerobic condition.

\section{Evaluation of sensory properties}

The sensory properties of the Labneh samples were determined by a panel of judges who were familiar with the product using the hedonic scale where 1-9 represents dislike extremely to like extremely (Tunde-Akintunde and Souley, 2009). The panelists analyzed the samples for colour, smell, texture, taste, appearance and mouth feel.

\section{Statistical analysis}

The obtained results were statistically analyzed using a software package (SAS, 1991) based on analysis of variance. When F-test was significant, least significant difference (LSD) was calculated according to Duncan (1955) for the comparison between means. The data presented, in the tables, are the mean $( \pm$ standard deviation) of 3 experiments.

\section{RESULTS AND DISCUSSION}

Yield and chemical composition of Labneh as affected by milk and culture types

Data of the obtained yield (Table 2) show that significant differences could be detected between the various treatments. The yield values of fresh Labneh were higher in treatments made from buffalo milk as compared with that made from soy milk. These outcomes are in agreement with the findings of Ammar et al., (1999) who stated that the yield of Labneh manufactured from buffalo milk was higher than that of cow or recombined milk. Raising the amount of salt added to Labneh's milk led to increase the yield and total solids of the product to some extent.

Utilization of ABT culture slightly lowered the yield values of Labneh apart from the type of milk used in manufacturing. It is seen from Table 2 that Labneh made from soy milk was relatively low acidic compared to that made from buffalo milk. Therefore incorporation of $25 \%$ soy milk with buffalo milk significantly ( $\mathrm{P}$ value; 0.0498 ) decreased the titratable acidity content of Labneh produced. Also, blending of soy milk with buffalo milk decreased $\mathrm{E}_{\mathrm{h}}$ values of Labneh. The $\mathrm{pH}$ values had the opposite trend of acidity and $E_{h}$ results. Acidity and $E_{h}$ values of classic starter Labneh treatments were relatively higher while $\mathrm{pH}$ data were lower than those of ABT Labneh. Moreover, the rise in titratable acidity and $\mathrm{E}_{\mathrm{h}}$ or drop in $\mathrm{pH}$ in classic starter Labneh was more than that observed in the ABT Labneh. This finding was in agreement with those of Hussein (2010) for yoghurt Opposite outcomes were found by El-Sayed et al., (2013) who reported that the $\mathrm{pH}$ decreased at similar rates within yoghurt treatments made using different combinations of normal yoghurt starter and probiotic B. bifidum and $L$. plantarum.

It can easily be observed from Tables 2 and 3 that there is a substantial effect of the milk type on TS, fat and ash contents of Labneh. Significant increases $(\mathrm{p}<0.05)$ in TS, fat and ash contents were obtained with using buffalo milk in Labneh production. Soy milk Labneh possessed the lowest TS, fat and ash contents. On the other side, classic starter Labneh gave TS, fat and ash results similar to Labneh prepared by ABT starter.

Significant $(\mathrm{p}<0.05)$ increasing in TN contents was noticed in Labneh made from buffalo milk as compared with that made from soy milk (Table 3). Accordingly, blinding of soy milk with buffalo milk lowered the TN contents of Labneh. TN contents of Labneh samples were not clearly affected by type of starter. 
Table 2 Yield and physicochemical composition of Labneh during storage period

\begin{tabular}{|c|c|c|c|c|c|c|}
\hline \multirow{2}{*}{ Properties } & \multirow{2}{*}{ Treatments } & \multicolumn{4}{|c|}{ Storage period (days) } & \multirow{2}{*}{ Means } \\
\hline & & Fresh & 7 & 14 & 21 & \\
\hline \multirow{6}{*}{$\begin{array}{l}\text { Yield } \\
\%\end{array}$} & $\mathrm{~A}$ & 25.01 & - & - & - & $25.10^{\mathrm{d}} \pm 1.02$ \\
\hline & $\mathrm{B}$ & 34.57 & - & - & - & $34.57^{\mathrm{a}} \pm 1.13$ \\
\hline & $\mathrm{C}$ & 30.08 & - & - & - & $30.08^{\mathrm{bc}} \pm 1.42$ \\
\hline & $\mathrm{D}$ & 24.33 & - & - & - & $24.33^{\mathrm{d}} \pm 1.22$ \\
\hline & $\mathrm{E}$ & 33.41 & - & - & - & $33.41^{\mathrm{ab}} \pm 1.11$ \\
\hline & $\mathrm{F}$ & 29.15 & - & - & - & $29.15^{\mathrm{c}} \pm 1.09$ \\
\hline \multirow{6}{*}{$\begin{array}{l}\text { Acidity } \\
\%\end{array}$} & $\mathrm{~A}$ & 0.91 & 0.98 & 1.09 & 1.25 & $1.06^{\mathrm{c}} \pm 0.02$ \\
\hline & $\mathrm{B}$ & 1.48 & 1.58 & 1.71 & 1.99 & $1.69^{\mathrm{a}} \pm 0.03$ \\
\hline & $\mathrm{C}$ & 1.34 & 1.43 & 1.54 & 1.76 & $1.52^{\mathrm{b}} \pm 0.05$ \\
\hline & $\mathrm{D}$ & 0.80 & 0.85 & 0.95 & 1.08 & $0.92^{\mathrm{c}} \pm 0.05$ \\
\hline & $\mathrm{E}$ & 1.37 & 1.45 & 1.55 & 1.78 & $1.54^{\mathrm{b}} \pm 0.03$ \\
\hline & $\mathrm{F}$ & 1.25 & 1.31 & 1.40 & 1.61 & $1.39^{\mathrm{b}} \pm 0.04$ \\
\hline \multirow{6}{*}{$\begin{array}{l}\text { pH } \\
\text { values }\end{array}$} & $\mathrm{A}$ & 4.98 & 4.87 & 4.75 & 4.58 & $4.79^{\mathrm{a}} \pm 0.42$ \\
\hline & B & 4.42 & 4.26 & 4.05 & 3.68 & $4.10^{\mathrm{a}} \pm 0.28$ \\
\hline & $\mathrm{C}$ & 4.50 & 4.37 & 4.29 & 3.98 & $4.28^{\mathrm{a}} \pm 0.33$ \\
\hline & $\mathrm{D}$ & 5.11 & 5.05 & 4.94 & 4.80 & $4.97^{\mathrm{a}} \pm 0.53$ \\
\hline & $\mathrm{E}$ & 4.51 & 4.38 & 4.20 & 3.93 & $4.25^{\mathrm{a}} \pm 0.47$ \\
\hline & $\mathrm{F}$ & 4.60 & 4.49 & 4.37 & 4.17 & $4.41^{\mathrm{a}} \pm 0.60$ \\
\hline \multirow{6}{*}{$\begin{array}{l}\mathbf{E}_{\mathrm{h}} \\
\mathbf{m V *}\end{array}$} & $\mathrm{A}$ & 83.6 & 92.7 & 99.5 & 110.9 & $96.7^{\mathrm{e}} \pm 3.11$ \\
\hline & $\mathrm{B}$ & 131.5 & 149.2 & 176.1 & 198.7 & $163.9^{\mathrm{a}} \pm 2.89$ \\
\hline & $\mathrm{C}$ & 128.3 & 143.2 & 165.9 & 189.4 & $156.7^{\mathrm{b}} \pm 2.56$ \\
\hline & $\mathrm{D}$ & 74.1 & 81.9 & 91.6 & 99.4 & $86.7^{\mathrm{f}} \pm 4.01$ \\
\hline & $\mathrm{E}$ & 125.7 & 142.6 & 161.9 & 181.4 & $152.9^{\mathrm{c}} \pm 3.21$ \\
\hline & $\mathrm{F}$ & 110.0 & 119.2 & 139.6 & 161.8 & $132.6^{\mathrm{d}} \pm 3.42$ \\
\hline \multirow{6}{*}{$\begin{array}{l}\text { TS } \\
\%\end{array}$} & $\mathrm{~A}$ & 27.80 & 27.93 & 28.23 & 28.40 & $28.09^{\mathrm{c}} \pm 1.23$ \\
\hline & $\mathrm{B}$ & 34.33 & 34.50 & 34.66 & 34.83 & $34.58^{\mathrm{a}} \pm 1.53$ \\
\hline & $\mathrm{C}$ & 32.17 & 32.33 & 32.46 & 32.63 & $32.40^{\mathrm{b}} \pm 1.85$ \\
\hline & $\mathrm{D}$ & 27.67 & 28.00 & 28.26 & 28.36 & $28.07^{\mathrm{c}} \pm 1.67$ \\
\hline & $\mathrm{E}$ & 34.73 & 34.89 & 35.13 & 35.20 & $34.99^{\mathrm{a}} \pm 1.57$ \\
\hline & $\mathrm{F}$ & 32.20 & 32.41 & 32.53 & 32.76 & $32.47^{\mathrm{b}} \pm 1.22$ \\
\hline
\end{tabular}

abcde Letters indicate significant differences between Rayeb milk treatments

*mV: millivolts

A: Labneh made from soy milk and classic starter; B: Labneh made from buffalo's milk and classic starter; C: Labneh made from $75 \%$ buffalo's milk $+25 \%$ soymilk and classic starter; D: Labneh made from soy milk and ABT culture; E: Labneh made from buffalo's milk and ABT culture; F: Labneh made from $75 \%$ buffalo's milk $+25 \%$ soymilk and ABT culture

\begin{tabular}{|c|c|c|c|c|c|}
\hline \multirow[t]{2}{*}{ Properties } & \multirow[t]{2}{*}{ Treatments } & \multicolumn{4}{|c|}{ Storage period (days) } \\
\hline & & Fresh & 7 & 14 & 21 \\
\hline \multirow{6}{*}{$\begin{array}{c}\text { Yield } \\
\%\end{array}$} & A & $25.10^{\mathrm{d}} \pm 1.02$ & - & - & - \\
\hline & $\mathrm{B}$ & $34.57^{\mathrm{a}} \pm 1.13$ & - & - & - \\
\hline & $\mathrm{C}$ & $30.08^{b c} \pm 1.42$ & - & - & - \\
\hline & $\mathrm{D}$ & $24.33^{\mathrm{d}} \pm 1.22$ & - & - & - \\
\hline & $\mathrm{E}$ & $33.41^{\mathrm{ab}} \pm 1.11$ & - & - & - \\
\hline & $\mathrm{F}$ & $29.15^{\mathrm{c}} \pm 1.09$ & - & - & - \\
\hline \multirow{6}{*}{$\begin{array}{c}\text { Acidity } \\
\%\end{array}$} & $\mathrm{~A}$ & $0.91^{\mathrm{dB}} \pm 0.01$ & $0.98^{\mathrm{cB}} \pm 0.01$ & $1.09^{\mathrm{cB}} \pm 0.01$ & $1.25^{\mathrm{cA}} \pm 0.01$ \\
\hline & $\mathrm{B}$ & $1.48^{\mathrm{aB}} \pm 0.01$ & $1.58^{\mathrm{aB}} \pm 0.01$ & $1.71^{\mathrm{aA}} \pm 0.01$ & $1.99^{\mathrm{aA}} \pm 0.01$ \\
\hline & $\mathrm{C}$ & $1.34^{\mathrm{bB}} \pm 0.01$ & $1.43^{\mathrm{aB}} \pm 0.01$ & $1.54^{\mathrm{bB}} \pm 0.01$ & $1.76^{\mathrm{bA}} \pm 0.01$ \\
\hline & $\mathrm{D}$ & $0.80^{\mathrm{dB}} \pm 0.01$ & $0.85^{\mathrm{cB}} \pm 0.01$ & $0.95^{\mathrm{cA}} \pm 0.01$ & $1.08^{\mathrm{cA}} \pm 0.01$ \\
\hline & $\mathrm{E}$ & $1.37^{\mathrm{bB}} \pm 0.01$ & $1.45^{\mathrm{aB}} \pm 0.01$ & $1.55^{\mathrm{bB}} \pm 0.01$ & $1.78^{\mathrm{bA}} \pm 0.01$ \\
\hline & $\mathrm{F}$ & $1.25^{\mathrm{cB}} \pm 0.01$ & $1.31^{\mathrm{bB}} \pm 0.01$ & $1.40^{\mathrm{bB}} \pm 0.01$ & $1.61^{\mathrm{bA}} \pm 0.01$ \\
\hline
\end{tabular}

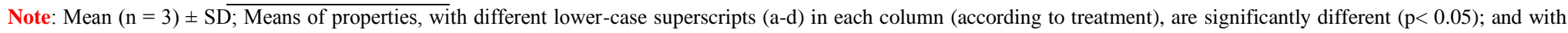
capital superscripts (A-B), within rows for each treatment, are significantly different ( $<<0.05)$; (one-way ANOVA and Duncan's test. a or A-the highest content).

Just as TN values increased in buffalo milk Labneh, also WSN contents raised. Addition of $25 \%$ soy milk to buffalo milk decreased WSN concentration. On the other hand, WSN contents were higher in Labneh made using classic culture as compared with that made by $\mathrm{ABT}$. This may be due to the high proteolytic activity of $L$. delbrueckii subsp. bulgaricus (Ammar et al., 2014).
Buffalo milk Labneh had the highest levels of TVFA whereas Labneh made from soy milk possessed the lowest (Table 3). This may be attributed to the high fat content of buffalo milk. Addition of soy milk to buffalo milk slightly decreased TVFA values of Labneh. Also using of ABT culture in manufacturing of Labneh lowered TVFA content. 
Table 3 Chemical composition of Labneh during storage period

\begin{tabular}{|c|c|c|c|c|c|c|}
\hline \multirow{2}{*}{ Properties } & \multirow{2}{*}{ Treatments } & \multicolumn{4}{|c|}{ Storage period (days) } & \multirow{2}{*}{ Means } \\
\hline & & Fresh & 7 & 14 & 21 & \\
\hline \multirow{6}{*}{$\begin{array}{l}\text { Fat } \\
\%\end{array}$} & $\mathrm{~A}$ & 7.4 & 7.4 & 7.4 & 7.5 & $7.4^{\mathrm{c}} \pm 0.12$ \\
\hline & B & 16.5 & 16.6 & 16.6 & 16.7 & $16.6^{\mathrm{a}} \pm 0.32$ \\
\hline & $\mathrm{C}$ & 14.1 & 14.1 & 14.2 & 14.2 & $14.1^{\mathrm{b}} \pm 0.52$ \\
\hline & $\mathrm{D}$ & 7.5 & 7.6 & 7.6 & 7.7 & $7.6^{\mathrm{c}} \pm 0.42$ \\
\hline & $\mathrm{E}$ & 16.4 & 16.5 & 16.5 & 16.6 & $16.5^{\mathrm{a}} \pm 0.63$ \\
\hline & $\mathrm{F}$ & 14.2 & 14.2 & 14.3 & 14.3 & $14.2^{\mathrm{b}} \pm 0.41$ \\
\hline \multirow{6}{*}{$\begin{array}{l}\text { Ash } \\
\%\end{array}$} & $\mathrm{~A}$ & 1.48 & 1.53 & 1.60 & 1.63 & $1.56^{\mathrm{c}} \pm 0.05$ \\
\hline & $\mathrm{B}$ & 1.76 & 1.83 & 1.90 & 1.98 & $1.87^{\mathrm{a}} \pm 0.04$ \\
\hline & $\mathrm{C}$ & 1.66 & 1.76 & 1.79 & 1.86 & $1.77^{\mathrm{a}} \pm 0.03$ \\
\hline & $\mathrm{D}$ & 1.50 & 1.59 & 1.65 & 1.69 & $1.63^{c} \pm 0.04$ \\
\hline & $\mathrm{E}$ & 1.73 & 1.79 & 1.86 & 1.94 & $1.83^{\mathrm{a}} \pm 0.02$ \\
\hline & $\mathrm{F}$ & 1.62 & 1.73 & 1.81 & 1.88 & $1.76^{\mathrm{ab}} \pm 0.01$ \\
\hline \multirow{6}{*}{$\begin{array}{l}\text { TN } \\
\%\end{array}$} & $\mathrm{~A}$ & 1.36 & 1.38 & 1.39 & 1.41 & $1.38^{\mathrm{d}} \pm 0.02$ \\
\hline & B & 1.90 & 1.91 & 1.94 & 1.95 & $1.92^{\mathrm{ab}} \pm 0.03$ \\
\hline & $\mathrm{C}$ & 1.75 & 1.77 & 1.78 & 1.80 & $1.77^{\mathrm{c}} \pm 0.02$ \\
\hline & $\mathrm{D}$ & 1.35 & 1.37 & 1.39 & 1.40 & $1.38^{\mathrm{d}} \pm 0.04$ \\
\hline & $\mathrm{E}$ & 1.91 & 1.93 & 1.95 & 1.97 & $1.94^{\mathrm{a}} \pm 0.05$ \\
\hline & $\mathrm{F}$ & 1.77 & 1.78 & 1.80 & 1.81 & $1.79^{\mathrm{bc}} \pm 0.02$ \\
\hline \multirow{6}{*}{$\begin{array}{l}\text { WSN } \\
\%\end{array}$} & $\mathrm{~A}$ & 0.335 & 0.357 & 0.385 & 0.430 & $0.377^{\mathrm{a}} \pm 0.007$ \\
\hline & B & 0.364 & 0.390 & 0.439 & 0.487 & $0.420^{\mathrm{a}} \pm 0.008$ \\
\hline & $\mathrm{C}$ & 0.352 & 0.376 & 0.415 & 0.460 & $0.401^{\mathrm{a}} \pm 0.005$ \\
\hline & $\mathrm{D}$ & 0.315 & 0.333 & 0.356 & 0.395 & $0.350^{\mathrm{a}} \pm 0.006$ \\
\hline & $\mathrm{E}$ & 0.358 & 0.380 & 0.421 & 0.464 & $0.406^{\mathrm{a}} \pm 0.005$ \\
\hline & $\mathrm{F}$ & 0.339 & 0.360 & 0.392 & 0.440 & $0.383^{\mathrm{a}} \pm 0.007$ \\
\hline \multirow{6}{*}{ TVFA* } & $\mathrm{A}$ & 9.6 & 10.2 & 12.6 & 14.8 & $11.8^{\mathrm{c}} \pm 0.89$ \\
\hline & B & 14.4 & 16.0 & 18.8 & 21.6 & $17.7^{\mathrm{a}} \pm 0.75$ \\
\hline & $\mathrm{C}$ & 13.4 & 15.0 & 17.2 & 19.8 & $13.3^{\mathrm{ab}} \pm 0.87$ \\
\hline & $\mathrm{D}$ & 9.0 & 9.4 & 11.4 & 13.6 & $10.8^{c} \pm 0.68$ \\
\hline & $\mathrm{E}$ & 14.0 & 15.4 & 17.8 & 20.4 & $16.9^{\mathrm{a}} \pm 0.55$ \\
\hline & $\mathrm{F}$ & 13.0 & 14.2 & 15.6 & 17.0 & $14.9^{b} \pm 0.75$ \\
\hline
\end{tabular}

abcde Letters indicate significant differences between Rayeb milk treatments

* expressed as ml $0.1 \mathrm{NaOH} 100 \mathrm{~g}^{-1}$ Labneh

\section{Free fatty acids content (FFA) of Labneh}

Data given in Tables 4 and 5 revealed that the saturated fatty acids (SFA) values of Labneh in all treatments were inversely proportional with the amount of unsaturated fatty acids (USFA). The concentration of SFA was higher than USFA in various Labneh treatments except samples A and D (soy milk Labneh). The results indicated that addition of $25 \%$ soy milk to buffalo milk markedly decreased the amount of SFA and inversely increased the amounts of USFA of Labneh. Value of SFA lowered by $9.17 \%$ while USFA content increased by $16.04 \%$ for sample C.

It could be viewed form Table 5 that utilization of ABT starter caused a markedly decrease in SFA and increase in USFA contents of fresh Labneh. Based on these results, combination of soy milk and $\mathrm{ABT}$ culture in one fermented dairy product like Labneh greatly reduced SFA content whereas highly raised USFA concentration. These findings are in agreement with the findings of Caglayan., $\boldsymbol{e}$ al., (2014) who found that the levels of USFA were slightly higher than SFA in probiotic Turkish yoghurt as compared with whole one. Lactic acid bacteria possess enzymes that are able to hydrolyze mono-, di- and triacylglycerols. The activity of the lipases depends strongly on the genera and bacteria species, as well as on the temperature and presence of calcium and magnesium ions (Nurliyani $\boldsymbol{e t}$ al., 2014)

Decreasing of SFA and increasing USFA values in soymilk bio-Labneh obtained in our study raise the healthy benefit of this product because it is well known that unsaturated fatty acids are more important in human nutrition. Siriwardhana $\boldsymbol{e t}$ al., (2012) showed that n-3 PUFAs are known to have variety of health benefits against cardiovascular diseases (CVDs) including well-established hypotriglyceridemic and anti-inflammatory effects.

Generally, the most predominant SFA found in various Labneh treatments was palmitic acid $\left(C_{16}\right)$ followed by stearic and myristic acids $\left(C_{14}\right)$. The highest acid ratio of USFA differed between treatments. For samples A and D (soy milk Labneh), the major acid of USFA was linoleic (18:2 $\omega 6)$ followed by oleic acid $(18: 1 \omega 9)$ whereas oleic acid was the corresponding one for samples B and E. For treatments $\mathrm{C}$ and $\mathrm{F}$, the first acid of USFA was oleic while the next was lionleic acid.

Marked differences in monounsaturated (MUSFA) and polyunsaturated fatty acids (PUSFA) fatty acids values were noticed when soymilk was used in manufacturing of Labneh (Tables 4 and 5). Labneh made from buffalo milk had higher contents of MUSFA than that made from soy milk. Incorporation of $25 \%$ soy milk with buffalo milk also decreased the amounts of MUSFA of Labneh. On the complete contrary, soy milk Labneh had the greatest amounts of PUSFA as compared with buffalo milk one. Addition of soy milk to buffalo milk highly increased levels of PUSFA.

It should be pointed out that using of ABT culture in Labneh manufacturing didn't cause pronounced changes in the contents of MUSFA and PUSFA. In all Labneh treatments except A and D, MUSFA values were higher than those of PUSFA. Samples A and D had the opposite trend. Oleic acid was found to have the greatest concentration of MUSFA in various Labneh treatments. The dominant fatty acid of PUSSFA was linoleic acid followed by $\alpha$-linolenic acid.

As it is well known, omega fatty acids are a group of essential fatty acids very important for human health. Soy milk Labneh (treatments A and D) characterized by very high contents of linoleic acid (omega-6) and $\alpha$-linolenic acid (omega-3) as compared with Labneh made from buffalo milk (samples B and E). Because of the ultra-high contents of linoleic and $\alpha$-linolenic acids in soy milk, replacement of $25 \%$ buffalo milk with soy milk highly increased the Labneh content from the two mentioned acids. Increasing rates were $333.67 \%$ for linoleic acid and $152.00 \%$ for $\alpha$-linolenic acid when $25 \%$ soymilk was added to buffalo milk (sample C). Concerning oleic acid (omega-9), incorporation of soy milk with buffalo milk slightly decreased the concentration of this acid in Labneh produced. The slight decline in oleic acid content does not reduce the importance of the vast increase in linoleic and $\alpha$-linolenic acids contents of Labneh when soymilk was used in manufacturing. The follow-up studies for many authors reported the healthy importance of linoleic and $\alpha$-linolenic acids. Simopoulos, (2002) cleared that the beneficial health effects of omega-3 fatty acids, eicosapentaenoic acid (EPA) and docosahexaenoic acid (DHA) were described first in the Greenland Eskimos who consumed a high seafood diet and had low rates of coronary heart disease, asthma, type 1 diabetes mellitus, and multiple sclerosis. Since that observation, the beneficial health effects of omega- 3 fatty acids have been extended to include benefits related to cancer, inflammatory bowel disease, rheumatoid arthritis, and psoriasis. Singh, (2005) showed that essential fatty acids (EFAs) are required for maintenance of optimal health but they cannot be synthesized in the body and must be obtained from dietary sources. 
Table 4 Effect of using soymilk on free fatty acids content of fresh Labneh

\begin{tabular}{|c|c|c|c|c|c|c|c|}
\hline \multirow{3}{*}{ Fatty acids } & \multirow{3}{*}{$\mathbf{C}$} & \multicolumn{6}{|c|}{ Treatments } \\
\hline & & $\mathbf{A}$ & $\mathbf{B}$ & $\mathbf{C}$ & D & $\mathbf{E}$ & $\mathbf{F}$ \\
\hline & & \multicolumn{6}{|c|}{ Saturated fatty acids (SFA) \% } \\
\hline Caprylic & 8:0 & 0.50 & 0.67 & 0.51 & 0.40 & 0.50 & 0.40 \\
\hline Capric & 10:0 & 1.10 & 1.93 & 1.79 & 1.09 & 1.29 & 1.13 \\
\hline Undecanoic & 11:0 & - & 0.42 & 0.28 & - & 0.20 & 0.20 \\
\hline Lauric & 12:0 & 1.59 & 2.93 & 2.24 & 1.39 & 2.10 & 1.94 \\
\hline Tridecanoic & 13:0 & 0.34 & 0.74 & 0.51 & 0.38 & 0.20 & 0.31 \\
\hline Myristic & 14:0 & 2.93 & 10.39 & 9.87 & 3.10 & 10.57 & 9.84 \\
\hline Pentadecanoic & $15: 0$ & 0.84 & 3.84 & 3.58 & 1.26 & 3.37 & 2.90 \\
\hline Palmitic & $16: 0$ & 15.51 & 27.00 & 24.52 & 14.90 & 27.21 & 24.58 \\
\hline Heptadecanoic & $17: 0$ & 0.47 & 2.00 & 1.86 & 0.24 & 2.48 & 2.17 \\
\hline Stearic & 18:0 & 5.99 & 12.34 & 11.31 & 5.40 & 12.67 & 11.23 \\
\hline Arachidic & 20:0 & 0.32 & 0.21 & 0.24 & 0.31 & 0.25 & 0.24 \\
\hline Behenic acid & $22: 0$ & 0.31 & 0.19 & 0.20 & 0.34 & 0.18 & 0.17 \\
\hline \multirow[t]{3}{*}{ Total } & & 29.90 & 62.66 & 56.91 & 28.81 & 61.02 & 55.11 \\
\hline & \multicolumn{7}{|c|}{ Unsaturated fatty acids (USFA) \% } \\
\hline & $12: 1 \omega 5$ & 0.50 & 0.58 & 0.54 & 0.53 & 0.56 & 0.35 \\
\hline \multirow[t]{2}{*}{ 5-Tetradecenoic (phytosteri) } & $14: 1 \omega 5$ & - & 0.34 & 0.46 & - & 0.56 & 0.50 \\
\hline & $14: 1 \omega 7$ & 0.25 & 0.38 & 0.52 & 0.30 & 0.39 & 0.31 \\
\hline \multirow[t]{2}{*}{ Myristioleic acid } & $14: 1 \omega 9$ & 0.40 & 0.34 & 0.63 & 0.44 & 0.36 & 0.34 \\
\hline & $16: 1 \omega 5$ & - & 0.14 & 0.11 & - & - & 0.13 \\
\hline \multirow[t]{2}{*}{ Palmitioleic } & $16: 1 \omega 7$ & 0.27 & 2.25 & 1.97 & 0.32 & 2.07 & 1.91 \\
\hline & $16: 2 \omega 4$ & - & 0.41 & 0.30 & - & 0.39 & 0.34 \\
\hline \multirow[t]{2}{*}{ Hexagonic } & $16: 3 \omega 4$ & - & 0.34 & 0.25 & - & 0.38 & 0.35 \\
\hline & $18: 1 \omega 4$ & - & 0.21 & 0.20 & - & - & 0.20 \\
\hline Octadecosaenoic & $18: 1 \omega 5$ & - & 0.48 & 0.47 & - & 0.30 & 0.31 \\
\hline Vaccienic & $18: 1 \omega 7$ & 1.42 & 1.90 & 1.58 & 1.49 & 1.93 & 1.70 \\
\hline \multirow[t]{3}{*}{ Oleic } & $18: 1 \omega 9$ & 21.00 & 24.39 & 22.17 & 20.74 & 23.90 & 23.10 \\
\hline & $18: 2 \omega 4$ & 0.97 & 0.66 & 0.50 & - & 0.85 & 0.77 \\
\hline & $18: 2 \omega 5$ & - & 0.24 & 0.20 & - & 0.38 & 0.35 \\
\hline \multirow[t]{2}{*}{ Linoleic } & $18: 2 \omega 6$ & 38.20 & 1.99 & 8.63 & 39.79 & 2.84 & 10.04 \\
\hline & $18: 2 \omega 7$ & - & - & 0.22 & - & 0.38 & 0.36 \\
\hline \multirow[t]{2}{*}{$\alpha$-Linolenic } & $18: 3 \omega 3$ & 4.77 & 0.75 & 1.89 & 5.58 & 1.04 & 2.11 \\
\hline & $18: 3 \omega 4$ & - & 0.13 & 0.15 & - & 0.15 & 0.15 \\
\hline Gamma linolenic & $18: 3 \omega 6$ & 0.15 & 0.12 & 0.17 & - & 0.15 & 0.15 \\
\hline Octadecatetraenoic & $18: 4 \omega 3$ & 0.21 & - & 0.18 & - & 0.44 & 0.21 \\
\hline Gadoleic acid & $20: 1 \omega 9$ & 0.15 & - & - & 0.16 & - & - \\
\hline Eicosaenoic & $20: 1 \omega 11$ & - & - & 0.23 & - & 0.43 & 0.21 \\
\hline \multicolumn{2}{|c|}{ Total } & 68.29 & 35.65 & 41.37 & 69.35 & 37.50 & 43.89 \\
\hline \multicolumn{2}{|c|}{ Non identified fatty acid } & 1.81 & 1.69 & 1.72 & 1.84 & 1.48 & 1.00 \\
\hline
\end{tabular}

Utilization of soy milk in Labneh making lowered the concentrations of shortchain fatty acids (C8 - C12) (SCFA) (Tables 4 and 5). Also, ABT-Labneh had lower SCFA contents than that made by classic culture. In different Labneh treatments, the fatty acid lauric $(\mathrm{C}: 12)$ was the predominant SCFA followed by capric acid (C10:0) and caprylic acid (C8:0). Beshkova et al., (1998) found that the formation of volatile free fatty acids $(\mathrm{C} 2-\mathrm{C} 10)$ was more active in the mixed yoghurt cultures than in the pure ones owing to the stimulating effect of protocoloperation between the two thermophillic species on the metabolic activities, which are responsible for the formation of free fatty acids. In fact, volatile acids is not only produced from lipolysis by lipases but also from several biochemical pathways including the fermentation of lactose or citrate and the degradation (oxidative deamination or decarboxylation) of amino acids (alanine and serine) which are the most important precursor of most volatile fatty acids (Kneifel $\boldsymbol{e t}$ al., 1992; Beshkova et al.,1998).

Medium chain fatty acids $\left(\mathbf{C}_{\mathbf{1 3}}-\mathbf{C}_{\mathbf{1 6}}\right)(\mathrm{MCFA})$ of Labneh took the same trend of SCFA where using soy milk in manufacturing led to decreasing of the content from these fatty acids (Tables 4 and 5). It has also been cleared from Table 5 that MCFA content of Labneh didn't affect by culture type. In different Labneh treatments, the concentration of palmitic acid $\left(\mathrm{C}_{16}\right)$ was the highest of MCFA and was followed by the concentrations of myristic $\left(\mathrm{C}_{14}\right)$.

The levels of long chain fatty acids (> C16) (LCFA) were very high in soy milk Labneh as compared with buffalo milk one. Mixing of $25 \%$ soy milk with buffalo milk also increased the content of Labneh from these acids. Furthermore, LCFA concentrations increased by using ABT culture in Labneh making. Among all the long chain fatty acids determined, the concentration of oleic and stearic acids were the highest in various Labneh samples except $A$ and D where the predominant acid of long chain fatty acids was linoleic acid followed by oleic acid. On a general note, the values of LCFA were higher than SCFA and MCFA in all Labneh samples. Similar results were found by El-Kadi et al., (2017) who reported that utilization of ABT culture in yoghurt production slightly lowered MCFA but raised LCFA levels as compared with classic starter.

Table 5 Effect of using soymilk on free fatty acid indices ratios of fresh Labneh

\begin{tabular}{cccccccc}
\hline Treatments & SFA & USFA & MUSFA & PUSFA & SCFA & MCFA & LCFA \\
\hline A & $29.90^{\mathrm{c}} \pm 1.11$ & $68.29^{\mathrm{a}} \pm 2.10$ & $23.99^{\mathrm{c}} \pm 1.12$ & $44.30^{\mathrm{a}} \pm 2.34$ & $3.69^{\mathrm{d}} \pm 0.75$ & $20.54^{\mathrm{c}} \pm 1.42$ & $75.77^{\mathrm{a}} \pm 0.89$ \\
B & $62.66^{\mathrm{a}} \pm 1.20$ & $35.65^{\mathrm{e}} \pm 1.99$ & $31.10^{\mathrm{a}} \pm 1.52$ & $4.55^{\mathrm{e}} \pm 0.44$ & $6.53^{\mathrm{a}} \pm 0.89$ & $46.17^{\mathrm{a}} \pm 1.53$ & $46.80^{\mathrm{c}} \pm 1.32$ \\
$\mathbf{C}$ & $56.91^{\mathrm{b}} \pm 1.31$ & $41.37^{\mathrm{c}} \pm 1.75$ & $28.88^{\mathrm{b}} \pm 1.41$ & $12.49^{\mathrm{c}} \pm 1.20$ & $5.46^{\mathrm{b}} \pm 0.56$ & $42.72^{\mathrm{b}} \pm 1.33$ & $51.42^{\mathrm{b}} \pm 0.78$ \\
$\mathbf{D}$ & $28.81^{\mathrm{d}} \pm 1.14$ & $69.35^{\mathrm{a}} \pm 1.86$ & $23.98^{\mathrm{c}} \pm 1.32$ & $45.37^{\mathrm{a}} \pm 3.53$ & $3.41^{\mathrm{d}} \pm 0.23$ & $20.70^{\mathrm{c}} \pm 1.62$ & $75.89^{\mathrm{a}} \pm 0.98$ \\
E & $61.02^{\mathrm{a}} \pm 1.15$ & $37.50^{\mathrm{d}} \pm 1.05$ & $30.50^{\mathrm{a}} \pm 1.60$ & $7.10^{\mathrm{d}} \pm 1.24$ & $4.25^{\mathrm{c}} \pm 0.52$ & $45.40^{\mathrm{a}} \pm 0.99$ & $50.35^{\mathrm{c}} \pm 1.34$ \\
F & $55.11^{\mathrm{bc}} \pm 1.20$ & $43.89^{\mathrm{b}} \pm 1.41$ & $29.06^{\mathrm{b}} \pm 1.23$ & $14.83^{\mathrm{b}} \pm 1.53$ & $4.02^{\mathrm{c}} \pm 0.33$ & $41.51^{\mathrm{b}} \pm 1.12$ & $54.47^{\mathrm{b}} \pm 1.62$ \\
\hline
\end{tabular}

SFA: saturated fatty acids; USFA: unsaturated fatty acids; MUSFA: monounsaturated fatty acids (C:1); PUSFA: polyunsaturated fatty acids (C:2+ C:3); SCFA: short chain fatty acids (C8 to C12); MCFA: medium chain fatty acids (C13 to C16); LCFA: long chain fatty acids (> $\mathrm{C} 16)$.

Free amino acids content (FAA) of Labneh

The change pattern of proteolytic activity during fermentation is of basic important for the degree of lactic acid bacteria. Proteinase activity was detected in several strains of lactobacilli and streptococci (Zourari et al., 1992). Results of Tables 6 and 7 illustrate the influence of using soy milk and ABT culture on the composition of FAA of fresh Labneh.
As shown in Tables 6 and 7, utilization of various kinds of milk or starter slightly impacted on the total free amino acids content of Labneh. Buffalo milk Labneh had the highest levels of the total free amino acids as compared to that prepared from soy milk. Mixing of $25 \%$ soy milk with buffalo milk has led to production of Labneh possessed the lowest total free amino acids content.

On the other side, utilization of ABT culture in Labneh making slightly raised the total free amino acids content. These results might be interpreted to mean that bacteria species has an effect on the content of amino acids in fermented dairy 
products. In all Labneh samples, the highest level of total free amino acids was that of glutamic acid, which is responsible for protection from cardiovascular diseases (Brosnan and Brosnan, 2013), followed by aspartic acid. On the contrary, methionine and cystine acids had the lowest content of total amino acids.

The concentrations of essential amino acids (EAA) were slightly higher in Labneh made from buffalo milk than those detected in Labneh made from soy milk. This is probably due to the high fat content of buffalo milk. Labneh made from mixtures $75 \%$ buffalo milk $+25 \%$ soy milk possessed slightly lower EAA levels than those of other treatments. Also, Labneh made from the above mentioned mixture had low values of essential amino acids to total amino acids $(\mathrm{E} / \mathrm{T})$ among the different treatments.

Because of low content of soy milk from sulfur amino acids (methionine and cysteine), Labneh made from it contained lower levels of these acids than that made from buffalo milk. Tabe and Higgins, (1998) reported that legumes (e.g., soybean, pea, bean, chickpea, alfalfa, lentil, clover) are mainly limited in the contents of sulfur amino acids, methionine and cysteine. Allman-Farinelli, (1998) showed that compared with protein found in egg and milk, soy bean contains less of the sulphur amino acids methionine and cycteine but there is a sufficient amount to regard soya protein as a high quality protein source.

Table 6 Effect of using soymilk on free amino acids content $(\mathrm{g} / 100 \mathrm{~mL})$ of fresh Labneh

\begin{tabular}{|c|c|c|c|c|c|c|}
\hline \multirow{2}{*}{ Amino acids } & \multicolumn{6}{|c|}{ Treatments } \\
\hline & $\mathbf{A}$ & B & $\mathbf{C}$ & D & $\mathbf{E}$ & I \\
\hline Aspartic (ASP) & 1.54 & 1.10 & 1.09 & 1.55 & 1.13 & 1.11 \\
\hline Threonine (THR) & 0.47 & 0.62 & 0.60 & 0.56 & 0.63 & 0.61 \\
\hline Serine (SER) & 0.66 & 0.65 & 0.68 & 0.70 & 0.68 & 0.64 \\
\hline Glutamic acid (GLU) & 2.55 & 2.37 & 2.40 & 2.57 & 2.38 & 2.41 \\
\hline Proline (PRO) & 0.82 & 1.53 & 1.28 & 0.82 & 1.55 & 1.29 \\
\hline Glycine (GLY) & 0.61 & 0.33 & 0.38 & 0.58 & 0.30 & 0.40 \\
\hline Alanine (ALA) & 0.72 & 0.53 & 0.58 & 0.74 & 0.56 & 0.61 \\
\hline Valine (VAL) & 0.83 & 0.96 & 0.90 & 0.83 & 0.93 & 0.94 \\
\hline Methionine & 0.22 & 0.45 & 0.36 & 0.25 & 0.47 & 0.32 \\
\hline Isoleucine (ILE) & 0.69 & 0.78 & 0.70 & 0.68 & 0.75 & 0.65 \\
\hline Leucine (LEU) & 1.13 & 1.36 & 1.21 & 1.17 & 1.35 & 1.25 \\
\hline Tyrosine (TYR) & 0.59 & 0.65 & 0.60 & 0.59 & 0.71 & 0.61 \\
\hline Phenylalanine (PHE) & 0.69 & 0.79 & 0.72 & 0.73 & 0.80 & 0.73 \\
\hline Histidine (HIS) & 0.41 & 0.49 & 0.45 & 0.42 & 0.55 & 0.47 \\
\hline Lysine (LYS) & 0.95 & 1.15 & 1.07 & 0.93 & 1.18 & 1.04 \\
\hline Arginine (ARG) & 1.04 & 0.65 & 0.74 & 1.07 & 0.60 & 0.70 \\
\hline Cystine (CYS) & 0.22 & 0.27 & 0.26 & 0.21 & 0.29 & 0.25 \\
\hline
\end{tabular}

It is apparent from the findings reported in Table 7 that bio-Labneh made using ABT had a little increasing of EAA than that made using classic starter. This may be due to the deference of bacteria species found in the starter. In all Labneh samples, the major essential amino acid was leucine followed by lysine. Methionine content was the lowest.

In contrast to trend of EAA, soy milk Labneh had the highest concentration of nonessential amino acid (Non-EAA) among different treatments. Utilization of ABT culture in Labneh preparation also increased the content of non-EAA Generally, glutamic and aspartic acids were predominant in different Labneh treatments.

Leucine, isoleucine, and valine possess a similar structure with a branched-chain residue and therefore are referred to as branched-chain amino acids (BCAA)
(Layman and Baum, 2004). Free BCAAs, especially leucine, play a very important role in protein metabolism; leucine promotes protein synthesis and inhibits protein degradation via mechanisms involving the mammalian target of rapamycin (Shimomura et al., 2004). These findings suggest that leucine is not only a building block of proteins but also a modulator of protein metabolism.

Labneh made from buffalo milk had slightly higher amounts of total BCAA than that made from soy milk (Tables 6 and 7). Thus, incorporation of buffalo milk with soy milk increased the Labneh content of total BCAA as compared with that made from only soy milk. On the other side, no pronounced differences were noticed in concentrations of total BCAA between Labneh prepared by classic or ABT culture. Leucine was the abundant acid of total BCAA for various samples.

Table 7 Effect of using soymilk on free amino acid indices ratios of fresh Labneh

\begin{tabular}{|c|c|c|c|c|c|c|}
\hline Treatments & $\begin{array}{c}\text { Total amino } \\
\text { acids }(\mathrm{g} / \mathbf{1 0 0 \mathrm { mL }})\end{array}$ & $\begin{array}{c}\text { Total EAA } \\
(\mathrm{g} / 100 \mathrm{~mL})\end{array}$ & $\begin{array}{l}\text { Total Non- } \\
\text { EAA } \\
\text { (g/100mL) }\end{array}$ & $\begin{array}{c}\text { Total BCAA } \\
(\mathrm{g} / 100 \mathrm{~mL})\end{array}$ & $\mathrm{E} / \mathrm{T}(\%)$ & $\begin{array}{c}\text { Total } \\
\text { BCAA/Total } \\
(\%)\end{array}$ \\
\hline $\mathbf{A}$ & $14.14^{\mathrm{a}} \pm 0.98$ & $5.39^{\mathrm{ab}} \pm 0.23$ & $8.75^{\mathrm{a}} \pm 0.52$ & $2.65^{\mathrm{ab}} \pm 0.12$ & $38.12^{\mathrm{c}} \pm 1.20$ & $18.74^{\mathrm{b}} \pm 1.11$ \\
\hline B & $14.68^{\mathrm{a}} \pm 1.23$ & $6.60^{\mathrm{a}} \pm 0.45$ & $8.08^{\mathrm{a}} \pm 0.74$ & $3.10^{\mathrm{a}} \pm 0.30$ & $44.96^{\mathrm{a}} \pm 1.30$ & $21.12^{\mathrm{a}} \pm 0.99$ \\
\hline $\mathrm{C}$ & $14.02^{\mathrm{a}} \pm 1.10$ & $6.01^{\mathrm{a}} \pm 0.62$ & $8.01^{\mathrm{a}} \pm 0.62$ & $2.81 \pm 0.14$ & $42.87^{b} \pm 1.51$ & $20.04^{\mathrm{ab}} \pm 0.85$ \\
\hline D & $14.40^{\mathrm{a}} \pm 0.78$ & $5.57^{\mathrm{ab}} \pm 0.51$ & $8.83^{\mathrm{a}} \pm 0.46$ & $2.68^{\mathrm{ab}} \pm 0.21$ & $38.68^{\mathrm{c}} \pm 1.62$ & $18.61^{\mathrm{b}} \pm 1.30$ \\
\hline $\mathbf{E}$ & $14.86^{\mathrm{a}} \pm 0.89$ & $6.66^{\mathrm{a}} \pm 0.87$ & $8.20^{\mathrm{a}} \pm 0.52$ & $3.03^{\mathrm{a}} \pm 0.51$ & $44.82^{a} \pm 1.63$ & $20.39^{\mathrm{a}} \pm 1.24$ \\
\hline $\mathbf{F}$ & $14.03^{\mathrm{a}} \pm 1.12$ & $6.01^{\mathrm{a}} \pm 0.23$ & $8.02^{\mathrm{a}} \pm 0.43$ & $2.84^{\mathrm{a}} \pm 0.21$ & $42.84^{\mathrm{b}} \pm 1.44$ & $20.24^{\mathrm{ab}} \pm 1.62$ \\
\hline
\end{tabular}

Total EAA: total essential amino acids; Total Non-EAA: total nonessential amino acids; Total BCAA: total branched-chain amino acids;

E/T: Ratio of essential amino acids to total amino acids.

\section{Microbial analysis of Labneh}

Labneh samples made from soy and buffalo milk using classic or ABT cultures were analyzed microbiologically for Streptococcus thermophillus, Lactobacillus bulgaricus, Lactobacillus acidophilus and Bifidobacterium bifidum. Data were recorded in Table 8. In various Labneh treatments, the counts of mentioned bacteria increased up to the seventh day then decreased till to the end of storage period. This reduction may be attributed to the high acidity produced by microbial fermentation (Dave and Shah, 1997). Similar results were obtained by other authors but with some variations. Ayyad et al., (2015) showed that the numbers of total viable count, B. bifidum, L. acidophilus and lactic acid bacteria of low fat Labneh increased up to the fourteenth day then decreased. Contrary, Hamad et al., (2014) cleared that numbers of L. acidophilus, S. thermophilus and bifidobacteria gradually lowered during storage of Labneh.

Results in Table 8 show that soy milk Labneh treatment had the greatest count of Str. thermophillus dislike Labneh made from buffalo milk which recorded the lowest count. This was the opposite of what was expected, because buffalo's milk is rich of elements and compounds more than soy milk, but may be soy milk as vegetarian milk contains some elements and compounds don't found or found with low levels in animal milk (buffalo) at the same time bacteria need that elements and compounds to grow well. As a sequence, blinding of $25 \%$ soy milk with buffalo or cow milk increased the count of Str. thermophillus in Labneh samples. In addition, loss of viability of these bacteria during storage period was lower in Labneh made from soy milk or mixtures of soy milk with buffalo milk comparing with that made from buffalo and cow milk. This may be due to the high acidity content and also the high acidity development rates in buffalo milk Labneh (Table 8). Loss of viability values of Str. thermophillus in samples A, B and $\mathrm{C}$ were $18.33,37.50$ and $22.03 \%$ respectively.

ABT Labneh treatments had the highest Str. thermophillus counts, meaning that the presence of $L$. acidophilus and B. bifidum clearly encouraged Str. thermophillus growth. This effect may be attributed to the low activity of acidity production of $L$. acidophilus and B. bifidum as compared with L. bulgaricus found in classic starter. Therefore, loss of survival values of Str. thermophillus were lower in ABT Labneh than those of classic starter one. Samples D, E and F had 5.55, 22.22 and $14.99 \%$ loss of survival of Str. thermophillus respectively.

With regard to L. bulgaricus, it is clear from Table 8 that type of milk has had great effect on counts of $L$. bulgaricus. These bacteria didn't have the ability to grow well in soy milk Labneh. Thus the loss of viability during storage increased with using soy milk in Labneh manufacturing. The highest counts of $L$. bulgaricus were in buffalo milk Labneh. The obtained results agreed with Sumarna, (2008).

Slight increases were observed in the viable number of L. acidophilus in Labneh made from soy milk only or mixed with buffalo milk. These results refer to using of soy milk in manufacturing of Labneh enhances the activity of L. acidophilus. 
The loss of survival levels during Labneh storage were 19.35, 48.15 and $32.14 \%$ for samples D, E and F respectively. Similar results were found by Hassanzadeh-Rostami et al., (2015).

It is clear from the results of Table 8 that bifidobacteria counts were higher in samples contained soy milk than those of buffalo milk which may be due to the activation effect of soy milk components on bifidobacteria. This means that our treatments had no worthless effect on these healthy bacteria. Furtherance of these results, the loss of viability rates of bifidobacteria throughout cold storage of Labneh also were lower in soy milk samples than other treatments. Loss of viability levels of samples D, E and F were $17.5,32.43$ and $18.42 \%$ respectively. Kamaly, (1997) stated that B. longum and B. bifidum exhibited proteolytic activity and were more pronounced in soy milk than in reconstituted skimmed milk.

It is necessary to maintain the probiotic bacteria numbers above $10^{6} \mathrm{cfu}^{-\mathrm{g}^{-1}}$ to give the beneficial probiotic effect. However the drop in the probiotic bacteria counts during storage time but they remained above $10^{6} \mathrm{cfu}_{\mathrm{g}} \mathrm{g}^{-1}$ in all Labneh samples. This main that the viability of strains after the storage period was sufficient to yield numbers of beneficial organisms that were higher than the accepted threshold $\left(10^{6} \mathrm{cfu}^{-1}\right)$ for a probiotic effect (Gomes and Malcata 1998). One of the possibilities of high stability of bifidobacteria at refrigerated storage in these samples could be the absence of Lb. delbrueckii ssp. bulgaricus which is known to produce post acidification. Post acidification could have further inhibitory effect on the $S$. thermophilus counts.

\section{Changes in sensory evaluation of Labneh}

The results given in Table 9 described the influence of addition soy milk and using ABT culture on the sensory evaluation of Labneh. Buffalo milk Labneh gained the highest scoring points of color and appearance followed by soy milk one. These findings clarify the effect of milk type on properties of Labneh. The bright white color of buffalo milk desirable to the Egyptians makes any dairy product the leader among other milk types. Mixing $25 \%$ soy milk with buffalo milk slightly decreased color and appearance values of Labneh. These results correspond with Osman and Abdel Razig (2010).

It is clear that the color and appearance scores of Labneh made using classic or ABT cultures were close to each other. Scores of color for fresh samples A and D were 8.50 and 8.50 respectively. These results are in agreement with those obtained by Ammar et al., (2015).

Table 8 Effect of using soymilk and ABT-5 culture on starter bacteria counts of Labneh

\begin{tabular}{|c|c|c|c|c|c|c|}
\hline \multirow{2}{*}{ Properties } & \multirow{2}{*}{ Treatments } & \multicolumn{4}{|c|}{ Storage period (day) } & \multirow{2}{*}{ Means } \\
\hline & & Fresh & 7 & 14 & 21 & \\
\hline \multirow{6}{*}{$\begin{array}{l}\text { Streptococcus } \\
\text { thermophillus } \\
\left(\mathrm{cfu} \times \times 10^{5} / \mathrm{g}\right)\end{array}$} & $\mathrm{A}$ & 60 & 84 & 70 & 49 & $65.7^{\mathrm{d}} \pm 3.12$ \\
\hline & $\mathrm{B}$ & 56 & 77 & 60 & 35 & $57.0^{\mathrm{f}} \pm 2.89$ \\
\hline & $\mathrm{C}$ & 59 & 81 & 65 & 46 & $62.7^{\mathrm{e}} \pm 3.11$ \\
\hline & $\mathrm{D}$ & 72 & 98 & 86 & 68 & $81.0^{\mathrm{a}} \pm 4.01$ \\
\hline & $\mathrm{E}$ & 63 & 86 & 72 & 49 & $67.5^{\mathrm{c}} \pm 2.98$ \\
\hline & $\mathrm{F}$ & 69 & 93 & 77 & 59 & $74.5^{\mathrm{b}} \pm 3.10$ \\
\hline \multirow{6}{*}{$\begin{array}{l}\text { Lactobacillus bulgaricus } \\
\left(\mathrm{cfu} \times \mathrm{x} 10^{5} / \mathrm{g}\right)\end{array}$} & A & 51 & 60 & 41 & 17 & $42.2^{\mathrm{c}} \pm 2.55$ \\
\hline & B & 67 & 95 & 80 & 58 & $75.0^{\mathrm{a}} \pm 2.68$ \\
\hline & $\mathrm{C}$ & 61 & 83 & 69 & 49 & $65.5^{b} \pm 3.52$ \\
\hline & $\mathrm{D}$ & - & - & - & - & - \\
\hline & $\mathrm{E}$ & - & - & - & - & - \\
\hline & $\mathrm{F}$ & - & - & - & - & - \\
\hline \multirow{6}{*}{$\begin{array}{l}\text { Lactobacillus } \\
\text { acidophilus } \\
\left(\mathbf{c f u} \times \mathbf{x} 10^{5} / \mathrm{g}\right)\end{array}$} & $\mathrm{A}$ & - & - & - & - & - \\
\hline & B & - & - & - & - & - \\
\hline & $\mathrm{C}$ & - & - & - & - & - \\
\hline & $\mathrm{D}$ & 31 & 36 & 33 & 25 & $31.2^{\mathrm{a}} \pm 2.11$ \\
\hline & $\mathrm{E}$ & 27 & 30 & 25 & 14 & $24.0^{\mathrm{c}} \pm 2.62$ \\
\hline & $\mathrm{F}$ & 28 & 30 & 27 & 19 & $26.0^{b} \pm 1.98$ \\
\hline \multirow{6}{*}{$\begin{array}{l}\text { Bifidobacterium bifidum } \\
\left(\mathrm{cfu} \times \mathrm{x}^{5} / \mathrm{g}\right)\end{array}$} & A & - & - & - & - & - \\
\hline & B & - & - & - & - & - \\
\hline & $\mathrm{C}$ & - & - & - & - & - \\
\hline & $\mathrm{D}$ & 40 & 47 & 42 & 33 & $39.4^{\mathrm{a}} \pm 3.41$ \\
\hline & $\mathrm{E}$ & 37 & 42 & 35 & 40 & $34.7^{\mathrm{b}} \pm 3.25$ \\
\hline & $\mathrm{F}$ & 38 & 44 & 40 & 31 & $38.2^{\mathrm{a}} \pm 2.97$ \\
\hline
\end{tabular}

Not only the white color that makes buffalo's milk favorite to the Egyptians, but also riches of fat. Therefore, it was not surprising that buffalo milk Labneh also obtained the highest scores of smell, taste and mouth feel evaluation tests. On contrary, soy milk Labneh recorded the lowest levels because of a beany flavor Incorporation of buffalo milk with soymilk markedly improved the smell, taste and mouth feel evaluation grades of Labneh

Because ABT culture produces mild acidity as compared with classic culture (Kurmann et al., 1992), using it in Labneh manufacture slightly improved the smell, taste and mouth feel properties. These findings agreed with that reported by Abd El-Salam et al., (2011).

In the same trend of scores of color, appearance, smell, taste and mouth feel, scores of texture and body were higher in buffalo milk Labneh than those of soy milk one. Unlike other characterizes of sensory evaluation, texture and body properties of soy milk Labneh were almost similar to those of Labneh made from buffalo milk. On the other hand, the texture and body scores of ABT Labneh slightly lowered than classic starter Labneh.

The last organoleptic property cleared in Table 9 was overall acceptability. Based on the results of sensory evaluation referred to previously, buffalo milk Labneh gained the highest scores of overall acceptability. Mixing of buffalo milk with soy milk improved the scores of overall acceptability of resulted Labneh. Regardless of milk type, utilization of ABT culture slightly increased the overall acceptability scores of fresh Labneh and during storage period.

During storage period, a slight drop in color, appearance, smell, taste, mouth feel texture, body and overall acceptability scores of all Labneh samples was evident. Similar results were reported by Salem et al., (2007).

\section{CONCLUSIONS}

It was found that synbiotic Labneh was successfully made from $75 \%$ buffalo milk and $25 \%$ soymilk mixture using of ABT culture. Utilization of soy milk reduced levels of saturated fatty acids and increased values of unsaturated fatty acids. Soy milk Labneh characterized by high amounts of omega 3 and 6 . The recommended level of $10^{7} \mathrm{cfu}^{-1}$ of bifidobacteria as a probiotic was exceeded for synbiotic Labneh. The results of sensory attributes evaluation showed that Labneh made from buffalo and soy milk mixture was acceptable especially at the beginning of storage period. 
Table 9 Effect of using soymilk and ABT-5 culture on sensory evaluation of Labneh

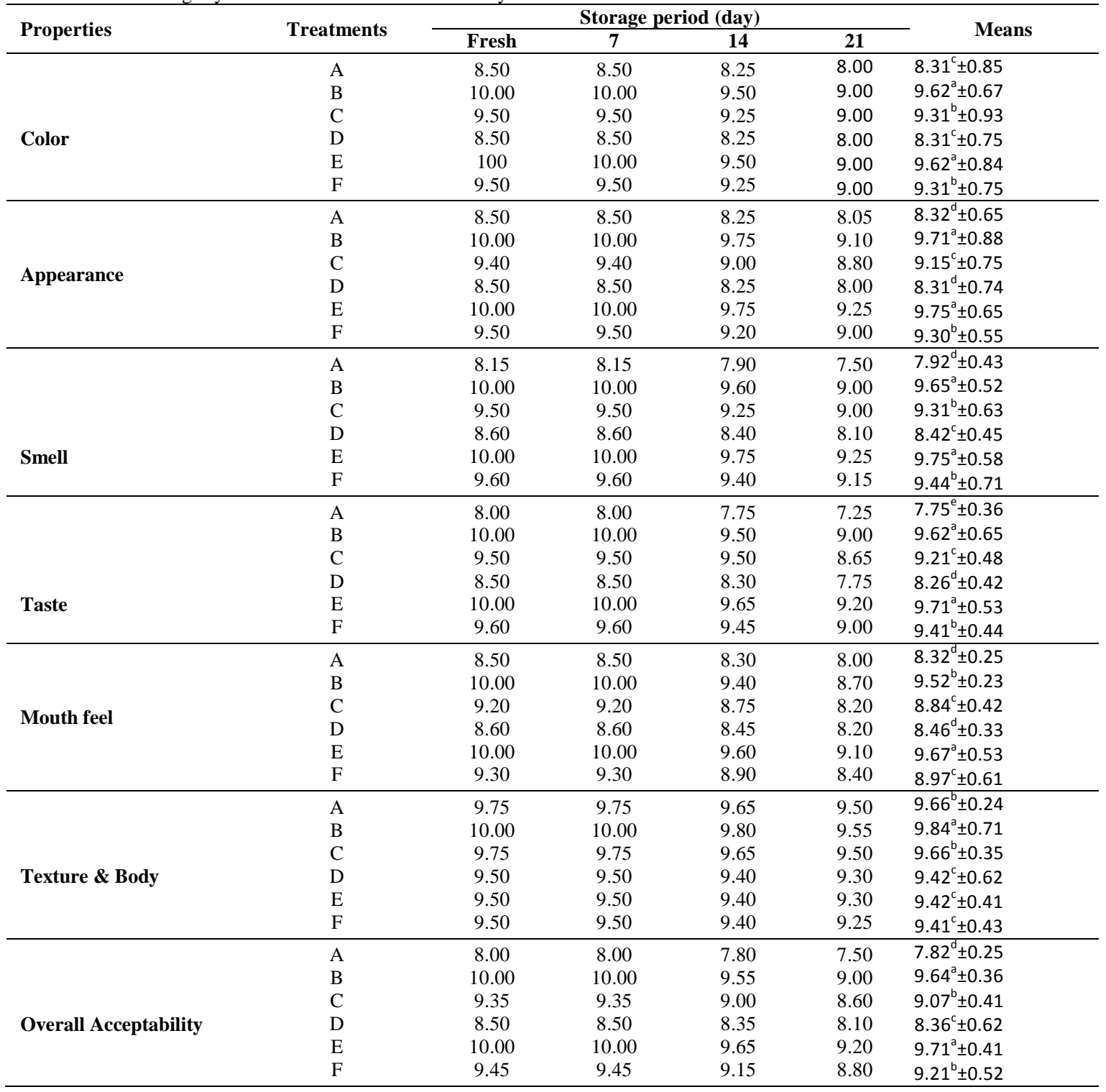

\section{REFERENCES}

Abd El-Salam, M.H., Hippen, A.R., El-Shafie, K., Assem, F.M., Abbas, H., Abd El-Aziz, M., Sharaf, O., El-Aassar, M. (2011). Preparation and properties of probiotic concentrated yoghurt (labneh) fortified with conjugated linoleic acid Int. J Food Sci. \& Tech. 46: 2103-2110. https://doi.org/10.1111/j.13652621.2011.02722.x

AlLman-Farinelli, M. (1998). Essential of Human Nutrition. Oxford University Press. Oxford.

Ammar, El-Tahra M.A., Ismail, M.M., Khalil, A.E., Eid, M.Z., (2015). Impact of fortification with honey on some properties of bio-yoghurt. J Microbiology, Biotechnology and Food Sci. 4: 503-508.

Ammar, El-Tahra, M.A., Ismail, M.M., KhaliL, A.E., Eid, M.Z. (2014). Effect of supplementation with olive oil on some properties of bio-yoghurt. The Asia $J$ Applied Microbiology, 1: 66-77. https://doi.org/10.15414/jmbfs.2015.4.6.503508

Ammar, M.A., EL-Shazly, A.A., Nasr, M.M., Omar, I.M.I. (1999). Comparative study on recombined Labneh, with buffalo and cow milk Laneh. I. Effect of level on consumer acceptability. Egyptian J. Dairy Sci. 27: 127-139.

AOAC 2000. Association of Official Analytical Chemists. Official Methods of Analysis. $17^{\text {th }}$ ed, Washington, DC, USA.

Ayyad, K.M., Abdul Ghaffar, I., Aida S. Salem, Ismail, M.M. (2015). Production of probiotic low fat Labneh by using exopolysaccacharide-producing strains. Egyptian J. Dairy Sci. 43: 41-51.

Beshkova, D., Simova, E., Frengova, G., Simov, Z. (1998). Production of flavour compounds by yogurt starter cultures. J. Ind. Micro. Biotechn. 20: 180186. https://doi.org/10.1038/sj.jim.2900504

Božanić, R., Rogelj, I., Tratnik, L.J. 2002. Fermentacijai čuvanje probiotičkog jogurta od kozjeg mlijeka. Mljekarstvo, 52, 93-111.
Božanić, R., Letikapić, P.G., Lovković, S. (2008). Influence of temperature and glucose addition on growth and survival of BCT culture in soymilk. Mljekarstvo, 58: 171-179.

Brosnan, J.T., Brosnan, M.E. (2013). Glutamate: a truly functional amino acid. Review. J Amino Acids. 45:413-418. https://doi.org/10.1007/s00726-012-1280-4 Caglayan, O., Cakmak, Y.S., Guler, G.O., Zengin, G., Aktumsek, A. (2014). Evaluation of fatty acid compositions of yogurts in Turkey. Asian J Chemistry, 26: 4871-4874. https://doi.org/10.14233/ajchem.2014.16323

Dave, R.I., Shah, N.P., (1997). Viability of probiotic bacteria in yoghurts made from commercial starter culture. Int. Dairy J. 7, 31-41. https://doi.org/10.1016/s0958-6946(96)00046-5

Dinakar, P., Mistry, V.V., (1994). Growth and viability of Bifidobacterium bifidum in Cheddar cheese. J. Dairy Sci. 77, 2854-2864. https://doi.org/10.3168/jds.s0022-0302(94)77225-8

Duncan, D.B. (1955). Multiple Range and Multiple F-test. Biometrics, 11: 1- 42 http://dx.doi.org/10.2307/3001478

El-Kadi, S.L., Ismail, M. M., Hamad, M. F., Zidan, M.S. (2017). Chemical and microbial characterizations of bio-yoghurt made using ABT culture, cow milk and coconut milk. J EC Microbiology 5: 109-124.

El-Sayed, S.M., Hagrass, A.E., Asker, A.A., Malhat, F.M., El-Sayed, M.M., Abd El-Salam, M.H. (2013). Effect of using some vitamin B producing microorganisms as adjunct cultures in the manufacture of yoghurt. Egyptian $J$. Dairy Sci. 4: 127-136.

Gomes, A., Malcata, F.X. (1998). Development of probiotic cheese manufacture from goat milk: Response surface analysis via technological manipulation. $J$ Dairy Sci. 81: 1492-1507. https://doi.org/10.3168/jds.s0022-0302(98)75715-7

Hamad, M.N., IsmaiL, M.M., Monira, M.M. Basiony (2014). Effect of fortification with whey protein on the chemical, microbial and organoleptical properties of Labneh. J. Food and Dairy Sci., Mansoura Univ. 5: 751-762. 
Hassanzadeh-Rostami, Zahra, Mazloomi, S.M., Rahmdel, S., Kazemi, Asma. (2105). Mixtures of soy- and cow's milk as potential probiotic food carriers. $J$ Biology and Today's World 4: 29-33. https://doi.org/10.15412/j.jbtw.01040105 Hussein, G.A.M. (2010). Preparation of yoghurt and probiotic yoghurt- like fermented products for bottle-fed infants. Egyptian J. Dairy Sci. 38: 171-182. Ikya, J.K., Gernah, D.I., OjobO, H.E., Oni, O.K. (2013). Effect of cooking temperature on some quality characteristics of soy milk. Advance J Food Sci. and Tech., 5: 543-546.

Jahreis, G.J., Fritsche, M.S.C., Steinhart, H. (1997). Conjugated linoleic acid in milk fat: High variation depending on production system. Nutrition Research 17 1479- 1484. https://doi.org/10.1016/s0271-5317(97)00138-3

Kamaly, K.M. (1997). Bifidobacteria fermentation of soybean milk. Food Research Int. 30: 675-682. https://doi.org/10.1016/s0963-9969(98)00039-8

Keceli, T., Robinson, R.K., Gordon, M.H. (1999). The role of olive oil in the preservation of yoghurt cheese (labneh anbaris). Int. Dairy Tech. 52: 68-72. https://doi.org/10.1111/j.1471-0307.1999.tb02074.x

Kneifel, W., Ulbert, F., Erhard, F., Jaros, D. (1992). Aroma profiles and sensory properties of yoghurt and yoghurt related products. I. Screening of commercially available starter cultures. Milchwissenchaft, 47: 362-365.

Kosikowski, F.V. (1978). Cheese and Fermented Milk Foods. 2nd ${ }^{\text {ed }}$. Cornell Univ. Ithaca, New York.

Kurmann, J.A., Rasic, J.L., Kroger, M. (1992). Encyclopedia of Fermented Fresh Milk Products: An International Inventory of Fermented Milk, Cream, Buttermilk, Whey and Related Products. 1st Edn., E. van Nostrand Reinhold, New York.

Layman, D.K. Baum, J.I. (2004). Dietary protein impact on glycemic control during weight loss. J Nutr. 134 (Suppl): S968-73.

Li, Q., Hu, Y., Chen, F., Wang, J., Liu, Z., Zhan, Z. (2014). Environmental controls on cultivated soybean phenotypic traits across China. Agric. Ecosyst. Enviro. 192: 12-18. https://doi.org/10.1016/j.agee.2014.03.034

Ling, E.R. (1963). A Text - Book of Dairy Chemistry. Vol. 2, Practical, $3^{\text {rd }}$ ed. Champan and Hall, London, England.

Mohameed, H.A., Abu-Jdayil, B., Al-Shawabkeh, A. (2004). Effect of solid concentration on the rheology of Labneh (concentrated yogurt) produced from sheep milk. J Food Engineering 61: 347-352. https://doi.org/10.1016/S02608774(03)00139-0

Nurliyani, Harmayani, E., Sunarti. (2014). Microbiological quality, fatty acid and amino acid profiles of kefir produced from combination of goat and soy milk". Pakistan J Nutrition 13: 107-115. https://doi.org/10.3923/pjn.2014.107.115

Osman, M.M.D., Abdel Razig, K.A. (2010). Quality attributes of soy-yoghurt during storage period. Pakistan J Nut. 9: 1088-1093. https://doi.org/10.3923/pjn.2010.1088.1093

Parmar, R. (2003). Incorporation of acid whey powders in probiotic yoghurt," M Sc. Thesis, Major in Biological Sciences, Specialization in Dairy, South Dakota State University, U.S.A.

Reilly, J.K., Lanou, A.J., Barnard, N.D., Seidl, K., Green, A.A. (2006) Acceptability of soymilk as a calciumrich beverage in elementary school children. J. Am. Diet. Assoc. 106: 590-593. https://doi.org/10.1016/j.jada.2006.01.010

Salem, M.M.E., Abd El-Gawad, Mona A.M., Hassan, Fatma A.M., Effat, B.A (2007). Use of synbiotics for production of functional low fat Labneh. Polish J. Food Nutr. Sci. 57: 151-159.

SAS. (1991). SAS User's guide: statistics. SAS Inst, Inc, Cary, NC

Shamsia, S.M., EL-Ghannam, M.S. (2012). Manufacture of Labneh from Cow's Milk Using Ultrafiltration Retentate With or Without Addition of Permeate Concentrate. J. Anim. Prod. Adv. 2:166-173.

Shimomura, Y., Murakami, T., Nakai, N., Nagasaki, M., Harris, R.A. (2004) Exercise promotes BCAA catabolism: effects of BCAA supplementation on skeletal muscle during exercise. J Nutr. 134 (Suppl): S1583-7.

Simopoulos, A.P. (2002). Omega-3 fatty acids in inflammation an autoimmune diseases. $J$ Am Coll Nutr. 21: 495-505 https://doi.org/10.1080/07315724.2002.10719248

Siriwardhana, N., Kalupahana, N.S., Moustaid-Moussa, N. (2012). Health benefits of n-3 polyunsaturated fatty acids: Eicosapentaenoic acid and docosahexaenoic acid. Advances in Food and Nutrition Res., 65: 211-222.

Sumarna (2008). Changes of raffinose and stachyose in soy milk fermentation by lactic acid bacteria from local fermented foods of Indonesian. Malaysian J Micro. 4: 26-34.

Tabe, L.M., Higgins, T.J. (1998). Engineering plant protein composition for improved nutrition. Trends in Plant Sci., 3: 282-286. https://doi.org/10.1016/s1360-1385(98)01267-9

Tamime, A.Y., Saarela, M., Korslund Sondergaard, A., Mistry, V.V., Shah, N.P (2005). Production and maintenance of viability of probiotic micro-organisms in dairy products. In: Tamime A.Y. (ed.): Probiotic Dairy Products. Blackwell Publishing Ltd, London: 39-72.

Tharmaraj, N., Shah, N.P. (2003). Selective Enumeration of Lactobacillus delbrueckii ssp. bulgaricus, Streptococcus thermophilus, Lactobacillus acidophilus, Bifidobacteria, Lactobacillus casei, Lactobacillus rhamnosus, and $\begin{array}{lllll}\text { Propionibacteria. } & J & \text { Dairy } & \text { Sci. } & \text { 86: }\end{array}$ 2296. _https://doi.org/10.3168/jds.s0022-0302(03)73821-1
Tunde-Akintunde, T.Y., Souley, A. (2009). Effect of processing methods on quality of soymilk. Pakistan J Nut. 8: 1156-1158.

Walsh, M.K., Brown, R.J. (2000). Use of amino acid analysis for estimating the individual concentrations of proteins in mixtures. J. Chromatogr. A. 891: 355 360. https://doi.org/10.1016/s0021-9673(00)00649-x

Zourari, A., Accolas, J.P., Desmazeaud, M.J. (1992). Metabolism and biochemical characteristics of yogurt bacteria. A review. Lait 72: 1-35 https://doi.org/10.1051/lait:199211 